\title{
The State of the Prisons
}

\section{"Disorder, disillusion, and disrepute"}

\author{
RICHARD SMITH
}

The British prison system is in a mess and so, almost inevitably, is an important part of it, the prison medical service.* The three main characteristics of the system are at the moment, according to Roy King and Rod Morgan, two academics who have made a close study of prisons, "disorder, disillusion, and disrepute." Those three words are carefully chosen. The disorder in the service is apparent to all, but the disillusion is less obvious, goes deeper, and is in many ways the most serious problem. The disrepute of the system, a particular problem for the medical service, presents extra problems but is not fully deserved. Many people in the prison service are working themselves to death, literally in some cases, trying to make the system work.

\section{A detailed and comprehensive look at prison health care}

In this series of articles I shall look in detail at the problems of delivering health care to prisoners. Although sensational and polemical articles on prison doctors appear regularly in the newspapers, and although sporadic articles written by and about prison doctors and on prison health care have been published in more sober publications, there has never been a detached, comprehensive, and detailed review of health care in British prisons. When he was deputy director of the prison medical service Dr Ronald Ingrey-Senn spoke to the Royal Society of Health and attacked the many critics of the prison medical

*To make these articles easier to read, I use prison medical service when I
mean that for England and Wales and will make it clear when talking about moan that for England and Wales and will

British Medical Journal, London WC1H 9JR

RICHARD SMITH, MB, CHB, assistant editor service by saying that many of them had "never bothered to read about the activities of the ... service." 2 But even if those critics had wanted to read about the service they would not have been able to find anything comprehensive.

Now they might as these articles are an honest attempt to provide such information, but I have come to realise that one

\begin{abstract}
"A prisoner is potentially in a worse condition than the slave, because the slave is the property of someone whose interest is to keep his property in serviceable condition, whereas the prisoner is owned by nobody, unless it be the State which is ultimately responsible for his imprisonment. Consequently the conditions of its prisons and its prisoners is no bad indication of the development of any society and its degree of civilisation."

Kenneth Ruck in his introduction to 1929 Everyman edition of John Howard's The State of the Prisons in England and Wales.
\end{abstract}

reason why nobody has attempted such articles before may be because they are extremely difficult to research and write. Clear and reliable information is hard to find. In the past year I have visited almost 20 prisons in five different countries. I have talked to prison doctors, prison nurses, specialists who visit prisons, forensic psychiatrists, psychologists, prison governors, and discipline officers, prison reformers, prisoners themselves and their spokesmen, academics who study prisons, bureaucrats who run them, and people whose job it is to inspect and audit them. Many of them have contradicted each other in what they have said.

I have looked as well at written material and found that there is little and that what does exist is mostly unscientific and 
polemical. Those of us who live in the scientific community are used to full publication of data, opinion, methods, arguments, and conclusions: nothing is certain, and everything is open to examination and argument. Usually the scientist and the scientific journalist are presented with an abundance of information, and their task is to sort out what is reliable and what is not. When it comes to studying prisons everything is different. There are a few good scientific studies of what goes on in prisons, but they are very few and mostly old. This is partly because rseaerch is difficult in prison and partly because it has not been encouraged.

How is an investigator, a journalist, to arrive at that elusive entity the truth when one side tells him one thing and the other side exactly the opposite and when he has so little reliable data to examine. $\mathrm{He}$ can look with his own eyes and listen with his own ears, you might answer, but that too is not easy. Not only does a prison, like a hospital, contain many worlds but those worlds often confront each other. Even in the most relaxed of our prisons it is still very much them and us, and both the them and the us are divided into disputing factions. Dr Mary Ellis, who was for 18 years the full time doctor at Feltham Borstal, gives us some insight into how one of those

factions regards some of the others in an article she published in the fournal of Adolescence ${ }^{3}$ :

"From our viewpoint outside interference (I use the word in the sense of how it feels to us) comes from headquarters whose injunctions to us are: be fair, obey the rules, keep us informed and don't make waves. From the probation officers whose message is: look after my lad, whom I failed and who failed me, treat him well and teach him a lesson, make me feel I did right to recommend custody, which I don't believe. From society which passes us a different message with each criminological theory to hit the headlines: treat them; don't have them at all; keep them in; get them out quickly; give them targets; punish them."

\section{Opening up the prisons}

British prisons have been closed, secretive places where communication is poor, contradictory, or non-existent ever since English, Welsh, and Scottish prisons were centralised in 1878. An amendment in 1922 to the 1911 Official Secrets Act applied to prisons. Professor Laurie Taylor argued in $1978^{4}$ that if John Howard, the great prison reformer whose book The State of the Prisons in England and Wales was published in $1777,{ }^{5}$ had been trying to make his investigations today then the Home Office would have stopped him. There have been several outstanding examples of where the Home Office has been painfully slow to produce important information-for instance, after the Hull riot of 1976 and the disturbance in D Wing of Wormwood Scrubs in $1979 .{ }^{6}$ After the Hull riot a Home Office inquiry exonerated prison staff, but two years later a court found eight prison officers guilty of charges arising from the riot. After the MUFTI (Minimum Use of Force Tactical
Intervention) squad had broken up a peaceful protest in Wormwood Scrubs the Home Office at first denied that any prisoners had been injured. Much later it was revealed that 53 prisoners had been injured and many had required stitches. No prison doctor spoke up after either of these incidents, and both are used as evidence by those who argue that prison doctors identify too much with the authorities.

Some critics of the British prison system have argued that its lack of visibility and so accountability is one of its biggest problems, ${ }^{7}$ and, interestingly, Viscount Whitelaw, the last Home Secretary, seemed partially to agree. He wrote in The Times in May 1983: "When I became Home Secretary in 1979 I set myself four objectives in prison policy. First, to open up the prisons to the media and so stimulate public interest and debate as the essential background to remedial action." 8 This is beginning to happen, and prisons have become more open in the past couple of years, but formidable problems remain for those who want to write serious, balanced articles on prisons. The lack of proper research is one problem, but the paranoia of parts of the prison service, particularly the medical service, is another.

When I started researching these articles I thought I would start with somebody I knew who works part time as a forensic psychiatrist in one of London's prisons. I arranged to meet him for a gentle lunch, but the day that we were to have the lunch he rang me up and said that it was impossible for me to meet him alone: we had to meet together with the acting head of the prison medical service-the same Dr Ingrey-Senn who had been deputy director. I resented this because I like to prepare my ground and ask those at the top questions at the end of my research. When I arrived, Dr Ingrey-Senn seemed to assume that I was just another journalist out to write a sensational attack on prison doctors, and he was hostile. Working on the principle of "no smoke without fire," as many journalists do, I might have assumed that he had something to hide, and if I could not find out exactly what it was I might have "invented" a story with the help of some of the many groups who are critical of the prison department and who have many lurid tales to tell. Eventually, Dr Ingrey-Senn softened and saw that I was making an honest attempt to write a dispassionate survey of the prison medical service, and he has since been most helpful. I am most grateful to him and the many prison doctors and officials who have mostly been very cooperative.

\section{Disrepute}

Dr Ingrey-Senn had good reason to be paranoid on that morning when I first met him for that very day he had been "having discussions" with the editor of World Medicine over an article that he was about to publish. The article, which I regard as sensational, distorted and missing the point, ${ }^{9}$ was accompanied by an extraordinarily strong leading article entitled "Perverted medicine."10 "The practice of medicine in 
prisons," it said, "is being perverted for reasons of political expediency... the system is one which enables bad doctors, incompetent and maybe worse, to practise without controls or scrutiny ... men and women in our prisons are receiving what amounts to punitive medicine." Such accusations have been heard often in the lay press, and there have been several libel actions-seemingly all of which the doctors have won. But the idea that prison doctors drug prisoners, close their eyes to brutality, identify with prison governors rather than prisoners, and think of prisoners as prisoners first and patients second is deeply rooted-among both the public and doctors. A further recent example of the bad image of the prison service was provided by reports about the evidence given by Inquest, 11 a prisoners' pressure group, to the Chief Inspector of Prisons as part of his inquiry into suicide in prisons. Inquest said that, as punishment, prison doctors have stitched up without anaesthetic the wounds of some prisoners who have tried to kill themselves.

These sorts of reports together with more balanced but scattered reports about the difficulties of the prison medical service have led me to try to find out more. In this series I will try to answer some of the following questions. What is the state of the prison medical service? How is the service organised and what are its aims? What are the differences between the systems in England and Wales, Scotland, and Northern Ireland? Does the service need reorganising ? Should it be fused with the NHS? What do prison doctors do? What types of medical problems are most common in prisons? Is prison medicine a specialty? Are prison doctors drugging their patients and abusing them in other ways? Do they identify more with the management than with prisoners? Is it possible to practise good medicine within the difficult conditions of the prisons? How can suicide be prevented within the prisons? How can the problem of the mentally disordered in prison best be managed? What is the condition of the other welfare services in prison? What are the particular problems of the young and women in prison? How do other countries run their prisons and provide medical care for inmates? Can we learn anything from them?

\section{A broader picture}

A further problem with writing articles on prison health care for a medical journal is that to concentrate on medical aspects while ignoring the broader problems of prisons is to run a grave risk of missing some of the roots of the problems and presenting only a superficial analysis. I have therefore devoted two articles to broader issues. Overcrowding, appalling conditions, rioting, rising costs, falling morale, lack of leadership, and difficulties in recruitment are all problems that confront those running the service, and I want to consider all of these briefly in the third article in the series. But perhaps the biggest problem, which is also the least easy to define, is lack of direction and purpose. What are the prisons for and what are they trying to achieve? John McCarthy, the governor of Wormwood Scrubs and one of the prison service's brightest stars, quit the service last year in a blaze of publicity over the prison department's failure to answer this question. ${ }^{12}$ But the question needs to be answered for only then can the right decisions be made about what direction the prison service should take. I will discuss

"San Quentin feels more tense to me than any other prison that I have visited. The prisoners are idle, and conditions in the prison are appalling. These two characteristics more than any others make for tension, and I think this prison could go up at any moment." A deputy governor of a large prison dictated sentences like these into a tape recorder on the evening of the day he visited San Quentin. Three days later three prisoners were murdered in San Quentin. The deputy governor continued his tour through the prisons of many countries, and when I met him he was confident that he had seen no prison system so uniformly bad as that in England and Wales. He had seen worse individual prisons in North America, but in England and Wales more than anywhere else did he see the dangerous cocktail of idleness and bad conditions. He found "the state of the prisons almost as depressing as did John Howard, the famous reformer, in his book published in 1777. My contact didn't want me to use his name because he felt a "loyalty with prison staff": he understood from the inside the difficult constraints of simultaneous public prurience and uninterest within which the staff work.

this important question in the next article. After the third article I will concentrate more directly on the medical aspects, but inevitably I will swing back at times-particularly when considering systems overseas-to broader prison issues.

\section{References}

' King RD, Morgan R, Martin JP, Thomas JE. The future of the prison system. Westmead, Hants: Gower, 1980

- Ingrey-Senn RC. Care and aftercare of prisoners: health care of prisoners whilst serving sentences. London: Royal Society of Health, 1979. (Available from RSH, 13 Grosvenor Place, London SW 1.)

${ }^{3}$ Ellis MJL. Conflict in an institutional setting: training and treatment considerations. 7 Adolesc 1980;3:115-31.

4 Taylor L. Onslaught on prison secrecy. New Statesman 1978 August 11

${ }^{5}$ Howard J. The state of the prisons in England and Wales. London: Everyman, 1929.

Evans P. Prison crisis. London: George Allen and Unwin, 1980.

- Fitzgerald M, Sim J. British prisons. Oxford: Basil Blackwell, 1982.

Whitelaw W. Prisons: no easy way out. The Times 1983 May 5:12.

9 Deer B. Doses with their "porridge." World Medicine 1982 Oct 30:28-9.

10 Anonymous. Perverted medicine. World Medicine 1982 Oct 30:7.

1 Anonymous. Gaol suicide cases "punished by pain." Guardian 1983 June $6: 4$.

12. McCarthy J. Taking liberties. Open Mind 1983 April/May:13. 